\title{
Termiczne pory roku w Poznaniu w latach 2001-2008
}

\author{
Thermal seasons in Poznań in the period 2001-2008
}

\author{
KATARZYNA SZYGA-PLUTA \\ Instytut Geografii Fizycznej i Kształtowania Środowiska Przyrodniczego, \\ Uniwersytet im. Adama Mickiewicza, \\ 61-680 Poznań, ul. Dzięgielowa 27; pluta@amu.edu.pl
}

\begin{abstract}
Zarys treści. W artykule przedstawiono charakterystykę termicznych pór roku w Poznaniu w latach 2001-2008. Na podstawie średnich dobowych wartości temperatury powietrza wyznaczono daty rozpoczęcia, końca oraz czas trwania 8 pór roku uwzględniając następujące progi termiczne: $0,0^{\circ} \mathrm{C}, 5,0^{\circ} \mathrm{C}, 10,0^{\circ} \mathrm{C}$ i $15,0^{\circ} \mathrm{C}$. Obliczono wská́niki opisujące te sezony oraz przedstawiono ich najistotniejsze cechy termiczne.
\end{abstract}

Słowa kluczowe: termiczne pory roku, średnia dobowa temperatura powietrza, Poznań.

\section{Wstęp}

Przejściowość klimatu Polski jest przyczyną ogromnej zmienności i różnorodności stanów pogody w ciągu całego roku, a szczególnie podczas pór przełomowych. Podział na astronomiczne pory roku nie odzwierciadla w pełni warunków pogodowych charakterystycznych dla danej pory roku. Podział roku na okresy wyznaczone za pomocą temperatury powietrza wydaje się dla rolnictwa i wielu dziedzin gospodarki bardziej odpowiedni. Wielu autorów skupia uwagę na zagadnieniu pór roku wyróżnianych na podstawie kryteriów termicznych. Stosuje się różne metody wyznaczania dat ich rozpoczęcia, uwzględniając wartości średnie miesięczne, dekadowe lub dobowe temperatury powietrza (m.in. Wiszniewski, 1960; Dubicka, 1996; Piotrowicz, 2000; Woś, 2006). Metody wyznaczania termicznych pór roku omawiają w swoich pracach R. Gumiński (1948), M. Makowiec (1983), K. Piotrowicz (2000, 2006). Różny też jest stosowany podział na termiczne pory roku, bo wyróżnia się ich od 6 do 10. Rozkład przestrzenny termicznych pór roku na obszarze Polski jest przedmiotem analizy T. Niedźwiedzia i D. Limanówki (1992) oraz A. Wosia (2010). Zróżnicowanie przestrzenne sezo- 
nów termicznych w mniejszej skali rozpatrują np. J.L. Olszewski i B. Jastrząb (1996) na obszarze środkowej części Gór Świętokrzyskich, B. OlechnowiczBobrowska i J. Wojkowski (2006) w południowej części Wyżyny KrakowskoCzęstochowskiej, B. Skowera i B. Kopeć (2008) w południowo-wschodniej Polsce. Termiczne pory roku w okolicach Zamościa w latach 2001-2008 scharakteryzowali A.S. Samborski i J. Bednarczuk (2009), a J. Tamulewicz (2001) przeprowadził porównanie sezonów termicznych Świnoujścia i Suwałk. Wieloletnich zmian termicznych pór roku dotyczą m.in. opracowania: M. Nowosada i E. Filipiuka (1998) - dla Lublina, J. Degirmendžicia i K. Kożuchowskiego (2004) dla Łodzi oraz U. Kossowskiej-Cezak (2005) dla Warszawy.

\section{Metody i zakres badań}

Celem niniejszego opracowania jest charakterystyka termicznych pór roku w Poznaniu w okresie 2001-2008. Przyjęto podział na osiem pór roku, słuszny - według W. Wiszniewskiego (1960) i M. Makowca (1983) - z fenologicznego punktu widzenia. Podział ten został przeprowadzony na podstawie określonych wartości progowych średniej dobowej temperatury: $0,0^{\circ} \mathrm{C}, 5,0^{\circ} \mathrm{C}, 10,0^{\circ} \mathrm{C}$ i $15,0^{\circ} \mathrm{C}$. Poszczególne temperatury progowe mają znaczenie dla wegetacji roślin, np. próg termiczny $5,0^{\circ} \mathrm{C}$ wyznacza rozpoczęcie okresu wegetacyjnego, przekroczenie temperatury progowej $10,0^{\circ} \mathrm{C}$ determinuje okres intensywnej wegetacji, a wartość progowa $15,0^{\circ} \mathrm{C}$ oznacza początek czasu dojrzewania. Długość okresu intensywnej wegetacji ma znaczenie przy waloryzacji obszarów na potrzeby regionalizacji upraw roślin o dużych wymaganiach cieplnych. Podział na 8 pór roku zastosowano również w Atlasie klimatu Polski (2005).

W niniejszej pracy przyjęto podział na poszczególne pory roku według następujących przedziałów średniej dobowej temperatury:

- przedwiośnie $0,0-4,9^{\circ} \mathrm{C}$,

- wiosna $5,0-9,9^{\circ} \mathrm{C}$,

- przedlecie $10,0-14,9^{\circ} \mathrm{C}$,

- lato od $15,0^{\circ} \mathrm{C}$,

- polecie $10,0-14,9{ }^{\circ} \mathrm{C}$,

- jesień $5,0-9,9^{\circ} \mathrm{C}$,

- przedzimie $0,0-4,9^{\circ} \mathrm{C}$,

- zima poniżej $0,0^{\circ} \mathrm{C}$.

Oparto się na wartościach średnich dobowych temperatury powietrza w Poznaniu w latach 2001-2008. Dane pochodzą ze stacji Instytutu Meteorologii i Gospodarki Wodnej Poznań Ławica (52²5’N, 1650'E, 86 m npm.). Wyznaczono terminy rozpoczęcia i zakończenia termicznych pór roku, czyli przejścia przez poszczególne wartości progowe w kolejnych latach oraz określono średnie daty z lat 2001-2008. Daty te wyznaczono na podstawie przebiegu średniej dobowej wartości temperatury oraz metodą graficzną. Duża zmienność 
średniej dobowej temperatury utrudnia wybór dat początku pór roku w niektórych latach. W takich przypadkach liczba dni właściwych stanowiąca większość oraz obliczona dla niejednolitego termicznie okresu średnia wartość temperatury pozwalała na zakwalifikowanie go do odpowiedniej pory roku. Obliczono czas trwania poszczególnych pór roku w każdym roku i badanym wieloleciu. Obliczono również zakres wahań dat początku oraz długość potencjalną, tzn. okres dzielący datę najwcześniejszego początku i datę najpóźniejszego końca danej pory roku w omawianym okresie. Pełniejszą charakterystykę pór roku stanowią informacje dotyczące warunków termicznych. W tym celu obliczono średnią temperaturę wszystkich sezonów termicznych. Ponadto obliczono częstość występowania dni właściwych, cieplejszych i chłodniejszych w poszczególnych porach roku, która odzwierciedla wahania średniej dobowej temperatury powietrza.

\section{Charakterystyka termicznych pór roku w Poznaniu w latach 2001-2008}

Przedwiośnie termiczne w Poznaniu rozpoczynało się w badanym okresie średnio 26 lutego (tab. 1), a kończyło 28 marca. Najwcześniej przedwiośnie rozpoczęło się 6 stycznia - w 2008 r., najpóźniej zaś 14 marca - w latach 2005 i 2006. Była to pora roku o największym zakresie wahań daty początku: 68 dni. W analizowanym okresie przedwiośnie trwało przeciętnie 31 dni. Najkrótsze było w 2005 r. - 9 dni, a najdłuższe w 2008 - 81. Potencjalna długość tej pory roku wynosiła 83 dni.

Średnia temperatura przedwiośnia termicznego na początku XXI w. w Poznaniu wyniosła 2,5 C (tab. 2). Najcieplejsze było przedwiośnie $2002 \mathrm{r}$. ze średnią dobową temperaturą $4,5^{\circ} \mathrm{C}$. Kolejne bardzo ciepłe, a jednocześnie najdłuższe w badanym okresie było przedwiośnie 2008 r. - średnia temperatura wynosiła wtedy $4,0^{\circ} \mathrm{C}$. Najchłodniejsze przedwiośnie wystąpiło w $2006 \mathrm{r}$. - było jednym z najkrótszych (trwało zaledwie 10 dni), a średnia temperatura wynosiła wtedy tylko $1,0^{\circ} \mathrm{C}$. W okresie wyznaczonym średnimi datami początku i końca przedwiośnia najczęściej (częstość 50\%) pojawiały się dni z dobową temperaturą charakterystyczną dla tej pory roku, czyli z przedziału $0,0-4,9^{\circ} \mathrm{C}$ (tab. 2). Przedwiośnie charakteryzowały częste adwekcje ciepła i nawroty chłodu. Zauważyć można dużą zmienność częstości występowania dni właściwych, chłodniejszych i cieplejszych w poszczególnych latach (ryc. 1). Dni cieplejsze, w których średnia temperatura mieści się w granicach 5,0-9,9 ${ }^{\circ} \mathrm{C}$, stanowiły średnio 24,4\%. Liczba dni chłodniejszych, z ujemną dobową temperatura powietrza, stanowiła przeciętnie $24,2 \%$ tej pory roku. Frekwencja dni ze średnią temperaturą dobową przekraczającą $10,0^{\circ} \mathrm{C}$ wynosiła $1,4 \%$ dni termicznego przedwiośnia. Podczas najcieplejszego przedwiośnia w 2002 r. dni cieplejsze 
stanowiły 56,5\%, natomiast w najchłodniejszym przedwiośniu w 2006 r. dni takie nie wystapiły wcale.

Początek termicznej wiosny przypadał w Poznaniu w latach 2001-2008 przeciętnie na 29 marca, a koniec na 21 kwietnia (tab. 1). Najwcześniej wiosna rozpoczęła się w 2007 r., tj. 28 lutego, było to jednak po okresie bez zimy termicznej. Najwcześniejsza wiosna przy wystąpieniu termicznej zimy przypadła na 15 marca 2004 r. Zakres wahań dat początku wynosił 31 dni. Najpóźniej, 30 marca, wiosna rozpoczęła się w 2001 r. Czas trwania wiosny w poszczególnych latach wyróżniał się dużą zmiennością. Najdłuższa wiosna trwała 39 dni w 2007 r. przy braku termicznej zimy, a 31 dni po zimie termicznej, w 2004. Długość wiosny średnio wynosiła 24 dni. Potencjalna długość tej termicznej pory roku w Poznaniu to 57 dni. Najkrótsza wiosna, zaledwie 11-dniowa, była w 2005 r.

Tabela 1. Daty początku i długość termicznych pór roku w Poznaniu, 2001-2008

Start days and duration of the thermal seasons in Poznań, 2001-2008

\begin{tabular}{|c|c|c|c|c|}
\hline \multirow[b]{2}{*}{$\begin{array}{l}\text { Pora roku } \\
\text { Season }\end{array}$} & \multicolumn{2}{|c|}{$\begin{array}{l}\text { Początek pory roku } \\
\text { Beginning of season }\end{array}$} & \multicolumn{2}{|c|}{$\begin{array}{l}\text { Długość pory roku } \\
\text { Duration of season }\end{array}$} \\
\hline & $\begin{array}{c}\text { data } \\
\text { (średnia) } \\
\text { date } \\
\text { (average) }\end{array}$ & $\begin{array}{c}\text { zakres wahań } \\
\text { (dni) } \\
\text { range } \\
\text { (days) }\end{array}$ & $\begin{array}{c}\text { średnia } \\
\text { (dni) } \\
\text { average } \\
\text { (days) }\end{array}$ & $\begin{array}{l}\text { potencjalna } \\
\text { (dni) } \\
\text { potential } \\
\text { (days) }\end{array}$ \\
\hline $\begin{array}{l}\text { Przedwiośnie } \\
\text { Early spring }\end{array}$ & $26 \mathrm{II}$ & 68 & 31 & 83 \\
\hline $\begin{array}{l}\text { Wiosna } \\
\text { Spring }\end{array}$ & 29 III & 31 & 24 & 57 \\
\hline $\begin{array}{l}\text { Przedlecie } \\
\text { Early summer }\end{array}$ & $22 \mathrm{IV}$ & 24 & 29 & 82 \\
\hline $\begin{array}{l}\text { Lato } \\
\text { Summer }\end{array}$ & $21 \mathrm{~V}$ & 55 & 113 & 154 \\
\hline $\begin{array}{l}\text { Polecie } \\
\text { Late summer }\end{array}$ & 11 IX & 31 & 31 & 56 \\
\hline $\begin{array}{l}\text { Jesień } \\
\text { Autumn }\end{array}$ & $12 \mathrm{X}$ & 24 & 28 & 82 \\
\hline $\begin{array}{l}\text { Przedzimie } \\
\text { Early winter }\end{array}$ & $9 \mathrm{XI}$ & 61 & 43 & 70 \\
\hline $\begin{array}{l}\text { Zima } \\
\text { Winter }\end{array}$ & 22 XII & 54 & 66 & 111 \\
\hline
\end{tabular}



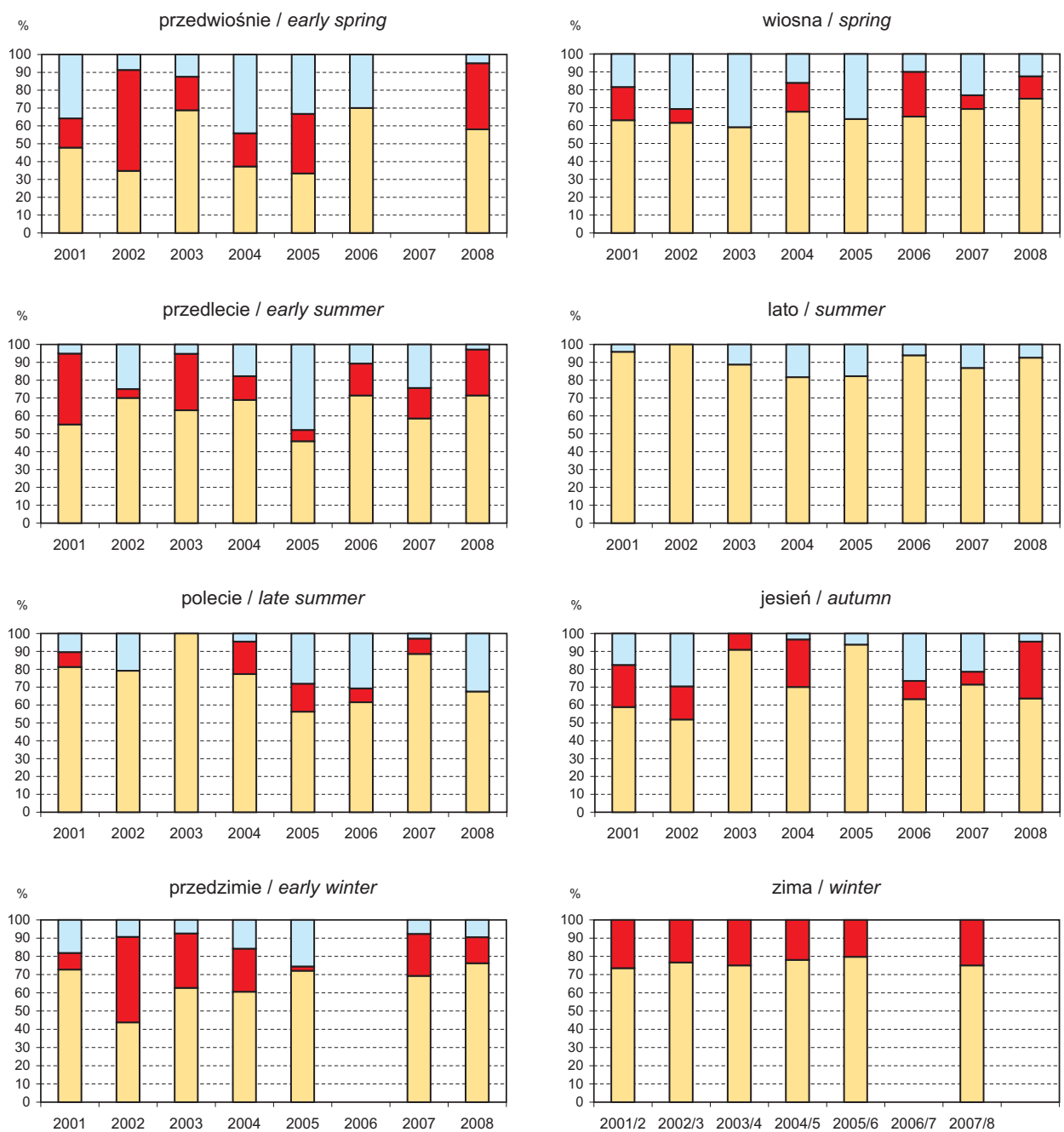

$\square$ dni właściwe / proper days $\quad \square$ dni cieplejsze / warmer days $\square$ dni chłodniejsze / colder days

Ryc. 1. Udział dni właściwych, cieplejszych i chłodniejszych w termicznych porach roku w Poznaniu, 2001-2008

Share of appropriate, warmer and colder days in the thermal seasons in Poznań, 2001-2008

Wiosnę termiczną w Poznaniu w latach 2001-2008 charakteryzuje średnia dobowa temperatura powietrza $6,5^{\circ} \mathrm{C}(\mathrm{tab} .2)$. Najcieplejszą wiosną była ta z 2006 r. Wystąpiła po bardzo krótkim i najchłodniejszym w badanym okresie przedwiośniu i odznaczała się średnią temperaturą $7,7^{\circ} \mathrm{C}$. W czasie najchłodniejszej wiosny w 2003 r. temperatura średnia była nieco niższa od dolnego progu temperatury tej pory roku i wynosiła $4,8^{\circ} \mathrm{C}$. Wiosnę cechuje duża 
zmienność stanów pogody i występowanie częstych fal chłodu; znajduje to odzwierciedlenie w niskiej temperaturze i liczbie dni chłodniejszych niż charakterystyczne dla tej pory roku. Dni właściwych dla termicznej wiosny było przeciętnie w omawianym okresie najwięcej, tj. 65,5\% (tab. 2). Ich frekwencja utrzymywała się na podobnym poziomie w kolejnych latach (ryc. 1). Ponad

Tabela 2. Średnia dobowa temperatura powietrza i częstość pojawiania się dni z temperaturą

średnią dobową w wyróżnionych przedziałach w poszczególnych termicznych porach roku w Poznaniu, 2001-2008

Mean 24-hour air temperature and frequency of occurrence of days with mean 24-hour air temperature in selected intervals in the thermal seasons in Poznań, 2001-2008

\begin{tabular}{|c|c|c|c|c|c|c|}
\hline \multirow[t]{2}{*}{$\begin{array}{l}\text { Pora roku } \\
\text { Season }\end{array}$} & \multirow{2}{*}{$\begin{array}{c}\text { Średnia } \\
\text { temperatura } \\
\text { dobowa } \\
\text { Mean diurnal } \\
\text { temperature } \\
\left({ }^{\circ} \mathrm{C}\right)\end{array}$} & \multicolumn{5}{|c|}{$\begin{array}{c}\text { Częstość (\%) dni z temperaturą średnią dobową } \\
\text { w przedziałach } \\
\text { Frequency (\%) of days with mean diurnal temperature } \\
\text { in intervals }\end{array}$} \\
\hline & & $<0,0^{\circ} \mathrm{C}$ & $0,0-4,9^{\circ} \mathrm{C}$ & $5,0-9,9^{\circ} \mathrm{C}$ & $10,0-14,9^{\circ} \mathrm{C}$ & $\geq 15,0^{\circ} \mathrm{C}$ \\
\hline $\begin{array}{l}\text { Przedwiośnie } \\
\text { Early spring }\end{array}$ & 2,5 & 24,2 & 50,0 & 24,4 & 1,4 & - \\
\hline $\begin{array}{l}\text { Wiosna } \\
\text { Spring }\end{array}$ & 6,5 & 3,2 & 20,3 & 65,5 & 11,0 & - \\
\hline $\begin{array}{l}\text { Przedlecie } \\
\text { Early summer }\end{array}$ & 12,4 & - & 0,5 & 16,9 & 63,0 & 19,6 \\
\hline $\begin{array}{l}\text { Lato } \\
\text { Summer }\end{array}$ & 18,8 & - & - & 0,1 & 9,7 & 90,2 \\
\hline $\begin{array}{l}\text { Polecie } \\
\text { Late summer }\end{array}$ & 11,9 & - & - & 16,3 & 76,4 & 7,3 \\
\hline $\begin{array}{l}\text { Jesień } \\
\text { Autumn }\end{array}$ & 7,6 & 0,3 & 13,4 & 70,5 & 15,4 & 0,4 \\
\hline $\begin{array}{l}\text { Przedzimie } \\
\text { Early winter }\end{array}$ & 2,8 & 14,1 & 64,4 & 20,6 & 0,9 & - \\
\hline $\begin{array}{l}\text { Zima } \\
\text { Winter }\end{array}$ & $-2,8$ & 79,7 & 20,2 & 0,1 & - & - \\
\hline
\end{tabular}

$20 \%$ dni termicznej wiosny stanowiły dni chłodniejsze, z tego $20,3 \%$ to dni z temperaturą $0,0-4,9^{\circ} \mathrm{C}$, a $3,2 \%$ - dni charakterystyczne dla termicznej zimy. Dni cieplejsze wiosną w Poznaniu w latach 2001-2008 występowały średnio z frekwencja 11,0\%. W latach 2003 i 2005 dni cieplejsze nie wystąpiły wcale. Największa liczba dni z temperaturą ujemną była charakterystyczna dla krótkiej i najchłodniejszej wiosny 2003 r. (18,2\%). 
Rozpoczęcie przedlecia w Poznaniu przypadało średnio w badanym okresie na 22 kwietnia, a zakończenie na 20 maja (tab. 1). Zakres wahań daty początku wynosił 24 dni; najwcześniej przedlecie rozpoczęło się 3 kwietnia (2005), a najpóźniej - 26 kwietnia (2001 r.). Średnio trwało 29 dni. Potencjalna długość tej pory roku to 82 dni; najdłuższe przedlecie trwało 59 (2001), a najkrótsze tylko 20 dni (2002 r.).

Średnia temperatura przedlecia wyniosła $12,4^{\circ} \mathrm{C}$ (tab. 2), wahając się od $10,1^{\circ} \mathrm{C}(2005)$ do $14,3^{\circ} \mathrm{C}$ (2001). Frekwencja dni właściwych dla tej pory roku wynosi 63,0\% (tab. 2). Dni z temperaturą powyżej $15,0^{\circ} \mathrm{C}$ średnio w przedleciu wystąpiło 19,6\%. W czasie najcieplejszego przedlecia w $2001 \mathrm{r}$. takie dni stanowiły około 40\% (ryc. 1), a dni chłodniejszych było prawie 17\%. Sporadycznie występowały dni z temperaturą nieprzekraczającą $10,0^{\circ} \mathrm{C}$. Zanotowano je tylko w najchłodniejszym przedleciu w $2005 \mathrm{r}$.

Termiczne lato rozpoczynało się przeciętnie 21 maja, a kończyło 10 września (tab. 1). Najwcześniej rozpoczęło się lato 2002 - 1 maja, a najpóźniej 2001 r. 24 czerwca. Zakres wahań daty początku wynosił 55 dni. Długość termicznego lata wahała się od 73 (2001) do 134 dni (2002 r.); średnio trwało 113 dni. Potencjalna długość termicznego lata to 154 dni.

Średnia temperatura termicznego lata w badanym okresie w Poznaniu wynosiła $18,8^{\circ} \mathrm{C}$ (tab. 2). Najcieplejszym termicznym latem na początku XXI w. było lato 2006 r. - średnia temperatura wynosiła wówczas $19,9^{\circ} \mathrm{C}$. Najchłodniejsze termiczne lato wystąpiło w 2004 r. i charakteryzowała je średnia temperatura równa $17,6^{\circ} \mathrm{C}$. Ponad $90 \%$ dni w lecie stanowiły dni właściwe (tab. 2). Frekwencja dni chłodniejszych była mała - 9,7\%. Tylko w 2005 r. wystąpiły w czasie termicznego lata sporadycznie $(0,8 \%)$ dni z temperaturą średnią dobową nawet poniżej $5,0^{\circ} \mathrm{C}$. W $2002 \mathrm{r}$. natomiast wszystkie dni mieściły się w przedziale temperatury charakterystycznej dla tej pory roku (ryc. 1).

Początek polecia w Poznaniu przypadał średnio na 11 września, a koniec na 11 października (tab. 1). Zakres wahań daty początku w badanym wieloleciu wynosił 31 dni. Najwcześniejszy termin rozpoczęcia to 2 września (2007), a najpóźniejszy 2 października (2006 r.). Średnio ta pora roku trwała 31 dni od 11 w 2003 do 48 w 2001 r., a potencjalna jej długość to 56 dni.

Średnia temperatura polecia w okresie 2001-2008 w Poznaniu wynosiła $11,9^{\circ} \mathrm{C}$ (tab. 2). Najcieplejsze polecie wystąpiło w 2004 i 2007 r., średnia temperatura była wówczas równa $13,0^{\circ} \mathrm{C}$. Najchłodniejsze było polecie z $2008 \mathrm{r}$., z temperaturą średnią dobową $10,7^{\circ} \mathrm{C}$. W okresie wyznaczonym średnimi datami początku i końca polecia najczęściej $(76,4 \%)$ pojawiały się dni z dobową temperaturą charakterystyczną dla tej pory roku, czyli $10,0-14,9{ }^{\circ} \mathrm{C}$ (tab. 2). Dni chłodniejsze stanowiły 16,3\% dni polecia, a frekwencja dni cieplejszych, ze średnią dobową przekraczającą $15,0^{\circ} \mathrm{C}$, wynosiła 7,3\%. W $2003 \mathrm{r}$. wszystkie dni mieściły się $\mathrm{w}$ przedziale temperatury charakterystycznej dla tej pory roku (ryc. 1). Największy udział dni cieplejszych charakteryzował rok 2004, czyli rok 
z najcieplejszym poleciem. W czasie najchłodniejszego polecia w 2008 r. zaznaczył się bardzo wysoki udział dni chłodniejszych - 32,5\%.

Najwcześniej w badanym wieloleciu termiczna jesień rozpoczęła się w 2003 (5 października), a najpóźniej w 2005 i 2006 r. (28 października) - tabela 1. Średnią datą początku termicznej jesieni w Poznaniu był 12 października. Była to pora roku (podobnie jak przedlecie) o najmniejszym zakresie wahań dat początku - 24 dni. Średnia długość tej pory roku to 28 dni, a potencjalna - 82 dni. Najdłuższa była jesień w 2006 r. - trwała 49 dni, a najkrótsza w 2003 -11 dni.

Termiczną jesień w Poznaniu charakteryzowała średnia dobowa temperatura powietrza $7,6^{\circ} \mathrm{C}$ (tab. 2). Wahała się ona od $6,6^{\circ} \mathrm{C}$ w 2002 do $8,5^{\circ} \mathrm{C}$ w $2004 \mathrm{r}$. $\mathrm{W}$ badanym okresie występowały dni z temperaturą o bardzo szerokim zakresie - od ujemnej do powyżej $15,0^{\circ} \mathrm{C}$ (tab. 2). Dominujący udział miały dni właściwe dla termicznej jesieni (70,5\%); dni cieplejsze $\left(10,0-14,9{ }^{\circ} \mathrm{C}\right)$ stanowiły $15,4 \%$ wszystkich dni jesiennych. Pojawiały się również dni z temperaturą średnią dobową powyżej $15,0^{\circ} \mathrm{C}$ (frekwencja 0,4\%), ale w 2005 r. dni cieplejszych nie było wcale (ryc. 1). Dni chłodniejszych, z temperaturą $0,0-4,9^{\circ} \mathrm{C}$, było średnio 13,4\%. Zdarzyły się też dni z ujemną temperaturą średnią dobową, ale tylko w jednej z najchłodniejszych jesieni, w 2006 r. (0,3\%).

Początek przedzimia w badanym okresie przypadał przeciętnie na 9 listopada, a koniec na 21 grudnia (tab. 1). Zakres wahań daty początku wynosił 61 dni. Najwcześniej przedzimie rozpoczęło się 16 października (2003 r.), a najpóźniej 16 grudnia (2006, kiedy nie wystąpiła termiczna zima) oraz 13 listopada (2005, kiedy termiczna zima wystąpiła). Najkrótsze przedzimie trwało 22 dni (2001), najdłuższe zaś - 76 (2004 r.); średnio trwało 43 dni. Potencjalna długość przedzimia wynosiła 70 dni.

Średnia temperatura dobowa podczas przedzimia w latach 2001-2008 w Poznaniu równa była $2,8^{\circ} \mathrm{C}$ (tab. 2). W najcieplejszym przedzimiu w $2002 \mathrm{r}$. średnia temperatura wynosiła $3,9^{\circ} \mathrm{C}$. Wtedy też największy udział $(43,8 \%)$, równy udziałowi dni właściwych dla tej pory roku, miały dni cieplejsze (ryc. 1). Najniższa średnia dobowa temperatura $-1,1^{\circ} \mathrm{C}$ - charakteryzowała przedzimie w 2005 r. Udział dni cieplejszych w ogólnej liczbie dni przedzimia był w tym roku najmniejszy, tj. 2,3\% (ryc. 1). Średni udział dni z zakresu odpowiadającego tej porze roku w latach 2001-2008 wynosił 64,4\% (tab. 2). Dni z temperatura ujemną pojawiały się w czasie przedzimia średnio z częstością 14,1\%. Dni cieplejsze stanowiły $20,6 \%$, a z temperaturą powyżej $10,0^{\circ} \mathrm{C}-0,9 \%$.

Na przełomie 2006 i 2007 r. nie wystąpiła termiczna zima. Termiczne przedzimie jest wtedy liczone od dnia spadku średniej dobowej temperatury powietrza poniżej $5,0^{\circ} \mathrm{C}$ do dnia ponownego przekroczenia tego progu tylko podczas wzrostu temperatury, czyli do daty rozpoczęcia termicznej wiosny. Termiczne przedzimie łączy się z termicznym przedwiośniem, tworząc jeden okres. Długość okresu „bezzimowego” w Poznaniu na przełomie 2006 i 2007 r. wynosiła 
$74 \mathrm{dni}$. Średnia dobowa temperatura powietrza równa była w tym okresie $2,9^{\circ} \mathrm{C}$. W tym czasie wystąpiły tylko następujące kilkudniowe okresy ze średnią dobową temperaturą poniżej zera: 25 i 27 grudnia 2006 r. oraz 22-26 stycznia, 7-10 lutego i 21-23 lutego 2007 r. Stanowiły one 18,9\% dni okresu „bezzimowego”. Udział dni z temperaturą średnią dobową o wartościach $0,0-4,9^{\circ} \mathrm{C}$ wynosił $55,4 \%$. W pozostałych dniach temperatura średnia dobowa przekroczyła $5,0^{\circ} \mathrm{C}$.

Średni termin rozpoczęcia termicznej zimy, czyli okresu z temperaturą poniżej $0,0^{\circ} \mathrm{C}$, przypadał na 22 grudnia, a zakończenia na 25 lutego (tab. 1). Zakres wahań daty początku wynosił 54 dni. Najwcześniejszy początek tej pory roku to 1 grudnia (2001), a najpóźniejszy 23 stycznia (2004 r.). Termiczna zima trwała w Poznaniu średnio 66 dni przy potencjalnej jej długości 111 dni. Najdłuższa zima (2003/2004) trwała 94 dni, natomiast najkrótsza 24 dni (w 2007 r.).

Termiczną zimę w Poznaniu w latach 2001-2008 charakteryzowała średnia dobowa temperatura równa $-2,8^{\circ} \mathrm{C}$ (tab. 2). Najcieplejsza była zima 2004/2005 z temperaturą średnią $-1,6^{\circ} \mathrm{C}$, a najchłodniejsza - 2005/2006 ze średnią równą $-3,7^{\circ} \mathrm{C}$. Prawie $80 \%$ dni termicznej zimy mieści się w zakresie temperatury odpowiadającym tej porze roku (tab. 2). Frekwencja dni właściwych w kolejnych latach była stabilna (ryc. 1). Pozostałe dni w większości lat badanego okresu to dni cieplejsze z temperaturą $0,0-4,9^{\circ} \mathrm{C}$, jedynie na przełomie lat 2002 i 2003 wystąpił w czasie termicznej zimy 1 dzień z temperaturą powyżej $10,0^{\circ} \mathrm{C}$.

\section{Podsumowanie}

W artykule przedstawiono charakterystykę termicznych pór roku w Poznaniu w latach 2001-2008. Na podstawie analizy podstawowych charakterystyk termicznych pór roku uzyskano następujące wyniki.

1. Średnie daty początku poszczególnych pór roku to: przedwiośnie 26 lutego, wiosna 29 marca, przedlecie 22 kwietnia, lato 21 maja, polecie 11 września, jesień 12 października, przedzimie 9 listopada i zima 22 grudnia.

2. Najkrótszą termiczną porą roku w Poznaniu była wiosna, a następnie jesień i przedlecie. Zdecydowanie najdłużej trwało lato. Średnia długość termicznych pór roku wynosiła: przedwiośnie 31 dni, wiosna 24, przedlecie 29, lato 113, polecie 31, jesień 28, przedzimie 43 i zima 66 dni.

3. Zauważono spore zróżnicowanie przebiegu pór roku w następujących po sobie latach - znaczna zmienność cechuje zarówno daty rozpoczęcia, jak i długość. Największy zakres wahań dat początku charakteryzował przedwiośnie (68 dni), a następnie przedzimie (61 dni). Najmniejszy zakres wahań dat początku wykazywały przedlecie i jesień (po 24 dni). Wahanie długości trwania poszczególnych pór roku wynosiło: przedwiośnie od 9 do 81 dni, wiosna od 11 do 39, przedlecie 20-59 dni, lato 73-134, polecie 11-48, jesień 11-49, przedzimie od 22 do 76 i zima od 0 do 94 dni.

4. Na przełomie roku 2006 i 2007 nie wystąpiła w Poznaniu termiczna zima. 
5. W analizowanym okresie stwierdzono wcześniejsze daty rozpoczęcia wiosny, przedlecia i lata niż w drugiej połowie XX w. (Woś, 2010). Lato i przedzimie wydłużyły się kosztem pozostałych pór roku.

6. Termiczne pory roku, poza wiosną, latem i zimą, wykazywały duże zróżnicowanie frekwencji dni właściwych w kolejnych latach. Zauważono także znaczne zróżnicowanie częstości występowania dni chłodniejszych i cieplejszych z roku na rok.

\section{Piśmiennictwo}

Atlas klimatu Polski, 2005, red. H. Lorenc, IMGW, Warszawa.

Degirmendžić J., Kożuchowski K., 2004, Zmiany termicznych pór roku w Łodzi w latach 1947-2003, [w:] 100 lat obserwacji meteorologicznych w Łodzi, Acta Geographica Lodziensia, 89, Łódź, s. 59-71.

Dubicka M., 1996, Termiczne pory roku we Wroctawiu, Acta Universitatis Wratislaviensis, 1794, Prace Instytutu Geograficznego, Seria C, Meteorologia i Klimatologia, 3, s. $5-31$.

Gumiński R., 1948, Próba wydzielenia dzielnic rolniczo-klimatycznych w Polsce, Przegląd Meteorologiczny i Hydrologiczny, 1, 1, s. 7-20.

Kossowska-Cezak U., 2005, Zmiany termicznych pór roku w Warszawie w okresie 1933-2004, Przegląd Geofizyczny, 50, 3-4, s. 265-277.

Makowiec M., 1983, Wyznaczanie termicznych pór roku, Przegląd Geofizyczny, 28, 2, s. 209-220.

Niedźwiedź T., Limanówka D., 1992, Termiczne pory roku w Polsce, Zeszyty Naukowe UJ, Prace Geograficzne, 90, s. 53-69.

Nowosad M., Filipiuk E., 1998, Zmiany czasu trwania termicznych pór roku w Lublinie w latach 1951-1995, Acta Universitatis Lodziensis, Folia Geographica Physica 3, s. 231-240.

Olechnowicz-Bobrowska B., Wojkowski J., 2006, Okresy termiczne w potudniowej części Wyżyny Krakowsko-Częstochowskiej (1992-2000), [w:] J. Trepińska, Z. Olecki (red.), Klimatyczne aspekty środowiska geograficznego, Instytut Geografii i Gospodarki Przestrzennej UJ, Kraków, s. 51-61.

Olszewski J.L., Jastrząb B., 1996, Termiczne pory roku w środkowej części Gór Świętokrzyskich, Roczniki Świętokrzyskie, seria B - Nauki Przyrodnicze, PAN - Oddział Kraków, Kieleckie Towarzystwo Naukowe, 23, s. 91-108.

Piotrowicz K., 2000, Sposoby wydzielania pór roku, Przegląd Geofizyczny, 47, 3-4, s. 261-278.

-, 2006, Pory roku - zastosowanie metod ich wyznaczania, [w:] K. Migała, P. Ropuszyński (red.), Wspótczesna meteorologia i klimatologia w geografii $i$ ochronie środowiska, PTG, Wrocław, s. 97-107.

Samborski A.S., Bednarczuk J., 2009, Termiczne pory roku w okolicach Zamościa w latach 2001-2008. Acta Agrophysica, 14, 1, s. 187-194.

Skowera B., Kopeć B., 2008, Okresy termiczne w Polsce potudniowo-wschodniej (19712000), Acta Agrophysica, 12, 2, s. 517-526.

Tamulewicz J., 2001, Termiczne pory roku w Świnoujściu i Suwatkach w latach 1966-1995, Badania Fizjograficzne nad Polską Zachodnią, Seria A - Geografia Fizyczna, 52, s. $175-189$. 
Wiszniewski W., 1960, Kilka uwag o meteorologicznych porach roku w Polsce w świetle średnich wieloletnich wartości temperatury, Przegląd Geofizyczny, 5, 1, s. 31-39.

Woś A., 2006, Termiczne pory roku w Poznaniu w drugiej połowie XX wieku, [w:] J. Trepińska, Z. Olecki (red.), Klimatyczne aspekty środowiska geograficznego, Instytut Geografii i Gospodarki Przestrzennej UJ, Kraków, s. 117-125.

-, 2010, Klimat Polski w drugiej połowie XX wieku, Wydawnictwo Naukowe UAM, Poznań.

[Wpłynęło: czerwiec; poprawiono: wrzesień 2010 r.]

\section{KATARZYNA SZYGA-PLUTA}

\section{THERMAL SEASONS IN POZNAŃ IN THE PERIOD 2001-2008}

On the basis of series of 24-hour air temperature values noted for Poznan in the 2001-2008 period, the work described here sought to characterize thermal conditions in the period overall, as well as in regard to the eight thermal seasons.

The durations of thermal seasons were determined in relation to the days on which air temperature crossed thermal thresholds of: $0.0^{\circ} \mathrm{C}, 5.0^{\circ} \mathrm{C}, 10.0^{\circ} \mathrm{C}$ and $15.0^{\circ} \mathrm{C}$. Defined in relation to mean air temperature values were: early spring $\left(0.0-4.9^{\circ} \mathrm{C}\right)$, spring $\left(5.0-9.9^{\circ} \mathrm{C}\right)$, early summer $\left(10.0-14.9^{\circ} \mathrm{C}\right.$ ), summer (above $15.0^{\circ} \mathrm{C}$ ), early autumn $\left(10.0-14.9^{\circ} \mathrm{C}\right)$, autumn $\left(5.0-9.9^{\circ} \mathrm{C}\right)$, early winter $\left(0.0-4.9{ }^{\circ} \mathrm{C}\right)$ and winter (below $\left.0.0^{\circ} \mathrm{C}\right)$. The courses for mean daily air temperature and the graphic method were applied to estimate the first and last days and durations of the thermal periods mentioned above (Table 1). A characterization of thermal conditions, including the frequency of occurrence of warmer, colder and appropriate days during the eight thermal seasons was produced (Table 2, Fig. 1).

The work reveals that, over the analyzed period, the shortest thermal season in Poznań was thermal spring (of 24 days' duration on average) and the longest summer (113 days). The greatest range of dates observed for the start of a season was the 68-day range characteristic for early spring. The most limited range of observed start dates in turn characterized the early summer and autumn (ranging across 24 days). Early spring shows the greatest variability to observed durations (lasting 9 days in 2005 and 81 days in 2008), while early summer is characterized by the most limited variability. Thermal winter lasted between 0 and 94 days and thermal spring between 11 and 39 days. There was a year without a thermal winter in the examined period observed in Poznań, between 2006 and 2007. There was great variability to the frequency of appropriate days in succeeding years in thermal seasons, excluding spring, summer and winter. 
http://rcin.org.pl 